\title{
Relationship Between Brand Engagement and Social Media Marketing
}

\author{
V. R. Neeraja, M. Nirmala Mohan
}

\begin{abstract}
This empirical study aims to explore the relationship between brand engagement and social media marketing among the students of higher education institutions in Chennai city of Tamil Nadu. This research study adopts primary survey method with the help of structured questionnaire collected from 388 students those who uses social media networking sites. The result indicates that Integration, $E-W o M$, Social Media Advertisement, Social Media Interaction and Brand Attitude are the major factors determining the brand engagement among students. The cluster classification and discriminant functions shows that two groups are significantly form namely, low brand engagement groups and high brand engagement groups in their order of dominance. To conclude, it is necessary to create interaction between the customer and brand and consumer to consumer to identify the impact of communication on brand equity.
\end{abstract}

Keywords : Social Media Marketing, Brand Engagement, Students and Attitude.

\section{INTRODUCTION}

In the recent past, the social network and information technology has tremendously changed with integrated of social media network modes. The information technology is plays a vital role in influencing the consumers part of their shifting from being un-reactive receiver information to becoming reactive recipients of information through social media networks. The mode of communication is completely changed among consumer interaction with retailer's brand which is completely different from a decade ago and the media marketing is the place where all kind of activities takes place (Brodie, \& et al., 2013; Keller, K. L., \& et al., 2011). In current scenario the social media marketing technique is booming in the market to reach the customers among retail brands (Constantinides, \& et al., 2008; Dehkordi, G. J., \& et al., 2012; Tuten, T. L. 2008) and this social media marketing platform is aid to promoting the retail brands and product to reach the customers with effective way (Lipsman, A., \& et al., 2012). The social media is the place where people share their views and opinion each to other with revolution of social media method of communication. Huge companies were taking part in social media to communicate with people

Revised Manuscript Received on December 05, 2019.

* Correspondence Author

V. R. Neeraja*, Full- Time Ph.D. Research Scholar, Department of (Autonomous), Chennai, Tamil Nadu - India

Dr. M. Nirmala Mohan, Associate Professor and Head, Department of Commerce (Shift - II), Department of Commerce, Madras Christian College (Autonomous), Chennai, Tamil Nadu - India Commerce (Shift - II), Department of Commerce, Madras Christian College

to know the actual needs and wants of the customers (Baird, C. H., \& Parasnis, G. 2011; Kaplan, A. M., \& Haenlein, M. 2010; Wang, X., \& et al., 2012).

Marketers are adopting social media networks as the first point to reach the customers and to know their needs and wants according to their requirements. This social media technique is possible to developing through the emerging social media network sites and the sites are Facebook, Twitter, WhatsApp, Instagram, LinkedIn, Snapchat, YouTube \& other sites. The marketers are day to day updating their products and services through the social media network pages to exploring the features of its. Social media marketing technique is being the bridge between the customer and brand to maintain a good relationship between them and engaged more actively with one another (Ashley, C., \& Tuten, T. 2015; Kang, J., \& et al., 2014; Wolny, J., \& Mueller, C. 2013; Evans, D. 2010; Bashar, A., \& et al., 2012). The social media marketing helps the retailers to understand customer needs and attitude of each person randomly and also to know the key factor contributing the best for customer needs through consumers brand identification in social network. Before a decade the brand correspondence has been controlled and designed by the brand, retailers or marketing managers but now it's completely moulded by the customers (De Chernatony, L. 1999; Falay, Z., \& et al., 2007). Social media marketing easily facilitate the retailer to sell the product at global level via social media anyone individual seller can be easily connected with the any consumer in person. Direct dealing in the market between the buyer and seller is highly possible only through the social media platform. The marketers can develop the business with the reviews and feedback with easy feasibility to contact the customers. Media marketing is the platform to sole trader who can sell their product or promote their product and increase wants for products by showing the videos of product by posting it in media platforms were people may get attracted and buy. Online shoppers are also connected with entrepreneurs to sell their product and many individual sellers are connected with e-tail giants i.e., AmaZon, FlipKart and others as seller to reach the buyer.

\section{SOCIAL MEDIA - BRAND ENGAGEMENT}

Marketer adopts social media as a tool to learn the customer needs and buying behavioral attitude. It helps the retailer to make the product better and reproduce with fine quality according to the taste and preference of the customer. 
It is to adopt and read the customer wants and also social media platform is the book to study the dos and don'ts of the brand according to the customer expectations. Customers can easily keep in touch with the retailers even to customize the product according to the personal taste and requirement of the individuals was easy via social media (Kotler, P., \& Zaltman, G., 1971). Customer post reviews and feedback of each shop or restaurant. All these observations are written in words in social media walls. More than advertising the personal bloggers is the game changer of the business. They write blogs according to their taste and preference but it makes the public to rate the retailers. Small traders are highly benefited in this way.

Brand is initially tested and shaped by every day on this new platform called social media for the research of marketer from the consumer to consumer connection (Kim, A. J., \& Ko, E., 2012; Lipsman., \& et al., 2012; Lamberton, C., \& et al., 2016; Kapoor, P. S., \& et al., 2013). And also personal chat is provided in each brand website. Just to chat with the customer in person to know the wants and to interact with the customers. Retailers concentrate on customer engagement and try to the maximum to make the customer to sustain to the particular brand (Jaakkola, \& Alexander., 2014). Maintaining the brand image is very important and to provide the same brand with same comfort zone to the customer. The brand image and brand loyalty is described by the service rendered by the retailer and the product never make to feel the customer to be better always best must be served to the customer. Added advantages or new improvements with the product must make the customers to feel better not to disappoint with the brand.

Brand awareness is very important to sustain and survive in the market. It refers to the extreme of how consumers are able to remember the brand or recognize the brand. Brand awareness is must and it is the key role to the business. It includes consumer behavior, advertisement which makes the customer to know about the product better, brand management and strategy development (Peter., \& et al., 1999; Myers, C. A. 2003). A customer is able to keep in mind one brand for long time or aware of such brand by using it or if the customer is stick on to the particular brand (Leone, \& et al., 2006; Tolba, A. H., \& Hassan, S. S. 2009). They are collectively known as Awareness, Attitude and Usage (AAU) metrics. Customer experience is known through the help of feedback forms or reviews or stars they give for the performance of the service rendered by the retailer and reviews about product after the usage of the product.

Customer engagement is the relationship between the retailer and customer on the basis of brand loyalty and brand awareness and services rendered through the brand. It is also known as relationship marketing. The relationship marketing is the long-term which is in-between the buyer and seller. Maintaining relationship as one to one relationship, retailer introduced the brand communities. It is created to interact with one particular brand community. Only a particular brand users has been taken part at one page to share the views and opinions about the brand and to create awareness among others about the product. Customer

engagement is about engaging the customer towards the brand keeping the customer busy and attractedtowards the brand not to move on or to look other brands in the market.

\section{STATEMENT OF PROBLEM}

Everyone can't access easily through the social media marketing. The middle age people or aged people are not much aware of the social media pages and also it's highly used by the educated people alone. Illiterates are not able to use the social media marketing effectively. It leads to create confusion among the consumers while they have too many options to buy which affects purchasing decision of the buyer. The retailers always concentrate on a particular set of customers who falls out of the box are not availing the service rendered by retailer. Those who use gadgets are only can use this social media marketing effectively.

\section{LITERATURE REVIEW}

Robert Davis and et al., (2014) revealed the study concepts of the brand in social media community and five sources model and authors have explored that the consumers are motivated the consumer to buy the products and to know more about the brand and designed the model to give a better understanding of the branding and brand relationships to social media users and brand managers. The examiners found that the employs a triangulated methods reveals that facebook focus on group and face-to-face interview. The empirical results of the study states that customer's expect roughly exact two-way interactions through brands and social media might be the only method to effectually carry the demands and the five core drivers of brand utilization in a social media community expressed in the Five Sources Model: functional, emotional, self-oriented, social and relational.

Kristina Heinoin (2011) explored the consumer activity in social media and managerial approaches to consumers' social media behaviour. Patrons are involved in a variable of actions, ranging from the consumption of the content to take part in negotiations, sharing information with other clients, and providing some valuable information's to other consumers' activities, and massive attention in social media sites, such as YouTube, Facebook, and Wikipedia, consumers are assumed to be aggressively contributing to marketing content. Though, in spite of the rich chances for contributing, current academic research designates that customers are not essentially as active online as has been believed. The study theorize customers' actions in social media by investigating the motivations overdue the happenings. The modifications in shopper practice of social media on consumer activities connected to user-created content. Based on purchaser descriptions of their social media activity, study identified fifteen activities assembled under three themes. The conceptual framework is cast-off to recommend decision-making policies associated to different stages of shopper activity. 
Michael Chih-Hung Wang and et al., (2018) examined the study "exploring the effects of social media-based brand community environment on consumer brand behavior". Social media-based brand community turns out to be an significant information network approach for marketing businesses. In spite of the increasing theoretical attention in the subject, little knowledge occurs on by what means social media-based brand community (hereafter SMBBC) can effect shopper brand estimation. Therefore, this study efforts to remedy the literature gap by assimilating the public integration model, rendezvous in the $\mathrm{OBC}$ or $\mathrm{SMBBC}$, and consumer brand evaluation to recommend a conceptual model for investigating the result of SMBBC set on purchaser brand evaluation. Also the study collected data from 402 respondents practiced in using SMBBC. The result exposed that SMBBC identification and company identification have an optimistic impression on brand engagement; whereas brand identification has a constructive effect on SMBBC engagement, peer identification has an encouraging influence on business credentials.

\section{OBJECTIVES OF THE STUDY}

1. To know the customers attitude towards the social media marketing

2. To analyse the relationship between the customer engagement towards brand engagement and brand loyalty.

3. To know the age group of the customers who access the social media marketing.

4. To know the customer experience and satisfaction towards brand communities.

\section{NEED AND SIGNIFICANCE OF THE STUDY}

- To know the customer accessibility towards the social media marketing.

- To determine the customer attitude towards the brand awareness and community.

- To entice all types of customers toward brand, and social media marketing.

- To know better about the consumers through the social media websites and motivating the customers to stick to a particular brand constantly.

- To know the effective customer engagement and improvements through customer experience on social media marketing.

- To know the customers purchasing experience through social media marketing.

\section{RESEARCH METHODOLOGY}

The study was empirically derived with data from cross sectional survey data. The research design of this study was both quantitative and descriptive in nature, and the selected sample was Chennai respondents those who are engaged social media platform towards brand practices. The sample for the study was 388 and non-probability convenience sampling technique has been applied to collect the primary data from the student users of social media brand engagers due to not available of comprehensive population in this study.

This survey is empirical and descriptive in nature. The survey questionnaire started with demographic and ended with variable specific question contain perception of social media usage towards brand engagement profile, followed by variables measuring the social media engagement practices towards brand attitude are measured by using five point Likert scale (1-Strongly Disagree, 5-Strongly Agree).

The sample size was limited to 388 due to time and cost constraint and application of non-probability convenient sampling to collect the primary data from respondents. After the data has been collected, it was processed using SPSS statistics 16 software package was used for the following analysis frequency, descriptive, test of normality, Cronbach's Alpha, cluster analysis, discriminant analysis and independent sample t-test have been applied.

Table 1: Demographic Characteristics

\begin{tabular}{|c|c|c|}
\hline Demographic Profile & Frequency & Percent \\
\hline \multicolumn{3}{|l|}{ Gender } \\
\hline Male & 212 & 54.6 \\
\hline Female & 176 & 45.4 \\
\hline \multicolumn{3}{|l|}{ Educational Qualification } \\
\hline Graduate & 112 & 28.9 \\
\hline Post - Graduate & 264 & 68.0 \\
\hline Professional and Others & 12 & 3.1 \\
\hline \multicolumn{3}{|l|}{ Marital Status } \\
\hline Married & 36 & 9.3 \\
\hline Unmarried & 352 & 90.7 \\
\hline \multicolumn{3}{|l|}{ Frequency of Login Social Media } \\
\hline Never Go Offline & 84 & 21.6 \\
\hline $2-4$ Times in a Day & 220 & 56.7 \\
\hline Once in a Week & 32 & 8.2 \\
\hline Occasionally & 52 & 13.4 \\
\hline \multicolumn{3}{|l|}{ Amount Spend for Shopping } \\
\hline$<$ Rs. 2000 & 300 & 77.3 \\
\hline Rs. 2001 to Rs. 4000 & 24 & 6.2 \\
\hline Rs. 4001 to Rs. 6000 & 16 & 4.1 \\
\hline$>$ Rs. 6000 & 48 & 12.4 \\
\hline
\end{tabular}

** Sample Size $=388$

Table 1 indicates that majority of the respondents are Male (54\%), Post-Graduates (68\%) and unmarried (90.7\%) students. Majority of the respondents are using social media $2-4$ Times in a day $(56.7 \%)$ and they spent less than Rs. 2000 for per purchase in social media $(77.3 \%)$. 
Relationship Between Brand Engagement and Social Media Marketing

Table 2: Descriptive Statistics \& Normality Test

\begin{tabular}{|c|c|c|c|c|c|c|c|c|}
\hline \multirow[b]{2}{*}{ Variables } & \multirow[b]{2}{*}{$\begin{array}{l}\text { No. of } \\
\text { Items }\end{array}$} & \multirow[b]{2}{*}{ Mean } & \multirow[b]{2}{*}{$\begin{array}{c}\text { Std. } \\
\text { Deviation }\end{array}$} & \multirow{2}{*}{$\begin{array}{c}\text { Skewness } \\
\text { Statistic } \\
\text { Std. Error = } \\
0.124\end{array}$} & \multirow{2}{*}{$\begin{array}{c}\text { Kurtosis } \\
\text { Statistic } \\
\text { Std. Error = } \\
0.247\end{array}$} & \multicolumn{2}{|c|}{ Tests of Normality } & \multirow{2}{*}{$\begin{array}{c}\text { Reliability } \\
\text { (Cronbach's } \\
\text { Alpha Value) }\end{array}$} \\
\hline & & & & & & $\begin{array}{c}\text { Kolmogorov-Smirnova } \\
\text { (Sig-Value) }\end{array}$ & $\begin{array}{c}\text { Shapiro-Wilk } \\
\text { (Sig-Value) }\end{array}$ & \\
\hline Integration & 6 & 3.1271 & 0.74623 & -0.555 & 0.291 & $0.109(0.000)$ & $0.970(0.000)$ & 0.738 \\
\hline E-WoM & 4 & 3.4000 & 0.91114 & 2.320 & 13.116 & $0.145(0.000)$ & $0.829(0.000)$ & 0.640 \\
\hline $\begin{array}{l}\text { Social Media } \\
\text { Advertisement }\end{array}$ & 4 & 3.1753 & 0.82997 & -0.392 & -0.268 & $0.117(0.000)$ & $0.970(0.000)$ & 0.739 \\
\hline Social Media Interaction & 4 & 3.2139 & 0.76839 & -0.494 & -0.301 & $0.148(0.000)$ & $0.952(0.000)$ & 0.656 \\
\hline Brand Attitude & 5 & 3.1155 & 0.74810 & -0.450 & 0.173 & $0.089(0.000)$ & $0.974(0.000)$ & 0.636 \\
\hline
\end{tabular}

The descriptive statistic and test of normality shows that the out of maximum value of 30 ( $5 \times 6$ Integration items), the mean value of 3.1271 is a robust measure of integration as the standard deviation is lower. The integration dimension distribution has a slight negative skewness. Out of maximum value of 20 ( $5 \times 4 \mathrm{E}-\mathrm{WoM}$ items), the mean value of 3.4000 is robust measure of E-Word of Mouth as the standard deviation is lower. The E-WoM distribution has a positive skewness. Out of maximum value of 20 ( 5 x 4 Social media advertisement recommendation variable), the mean value of 3.1753 is a robust measure of social media advertisement recommendation as the standard deviation is lower. The

social media advertisement recommendation distribution has a slight negative skewness. Out of maximum value of $20(5 \mathrm{x}$ 4 Social media interaction), the mean value of 3.2139 is robust measure of social media interaction as the standard deviation is lower. The social media interaction distribution has a slight negative skewness. Out of maximum value of 25 ( $5 \times 5$ brand attitude items), the mean value of 3.1155 us a robust measure of brand attitude dimension distribution has a slight negative skewness. Test of normality values of the both test such as Kolmogorov-Smimove and Shapiro-Wilk are the indication of normality in the data collected from the respondents for all dimensions and Cronbach's also proved value as per recommended thresholds $(>0.50)$.

\section{Figure 1.1: Consumer Brand Equity - E-WoM - Model}

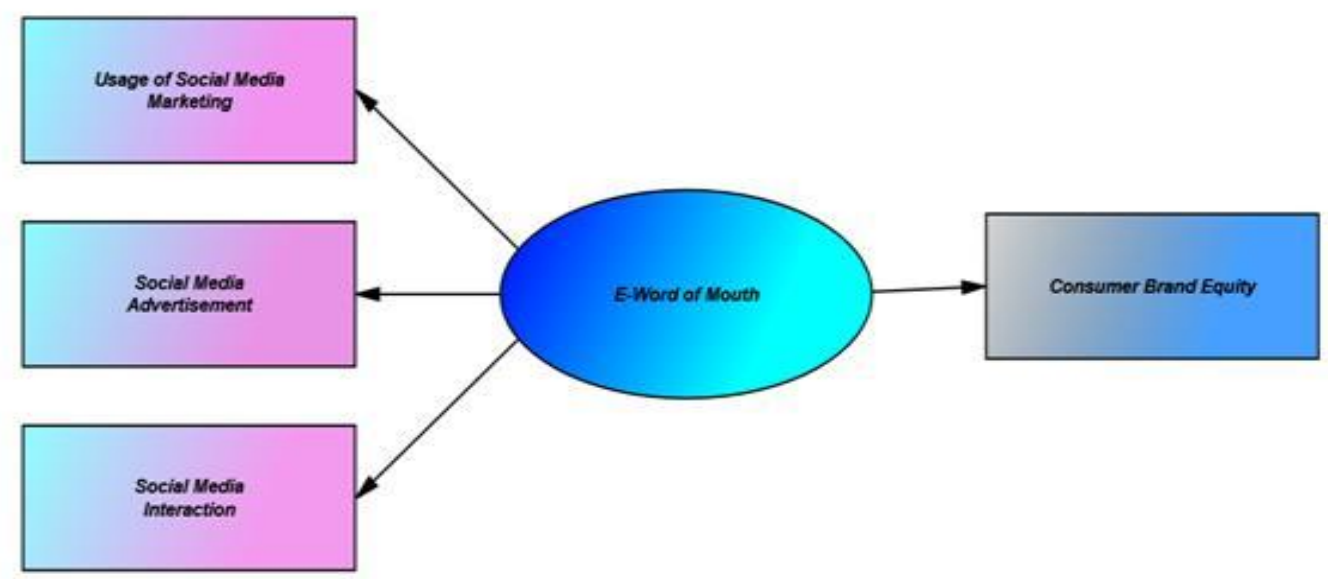

Integration: Customer integration is the module of purchaser association management which puts technology and branding relationship which allows the buyers to reach the organization directly. It is used to collect information from website to know about the product and consumer can use social media pages and branding company's website to learn about the product.

E-WoM: Electronic word of mouth is form marketing to promote the product through social media or through internet. Spreading a word about the brand through internet is known as e-word of mouth. And branding is done through the social media marketing with the help of internet.

Social Media Advertisement Recommendation: Social media advertisement attracts the customer to buy the product or stick on to a particular brand. It is to recommend the product and to serve the users more information about the product. Social Media Interaction: Social media interactions is useful to interact with the brand sellers regarding the purchase or to know the about the product. And also it is used to convey the wants of customer to brand seller or can convey the customizations.

Brand Attitude: Brand attitude is the consumer opinion towards the brand or product which resolute through market research. The brand attitude reveals how customer feel about the product or service, and it shows whether the product satisfies the customer wants and it gives the result and it shows the customer wants and needs towards the product. 
Table 3: Cluster Groups of the Respondents based on the Brand Attitude Factors

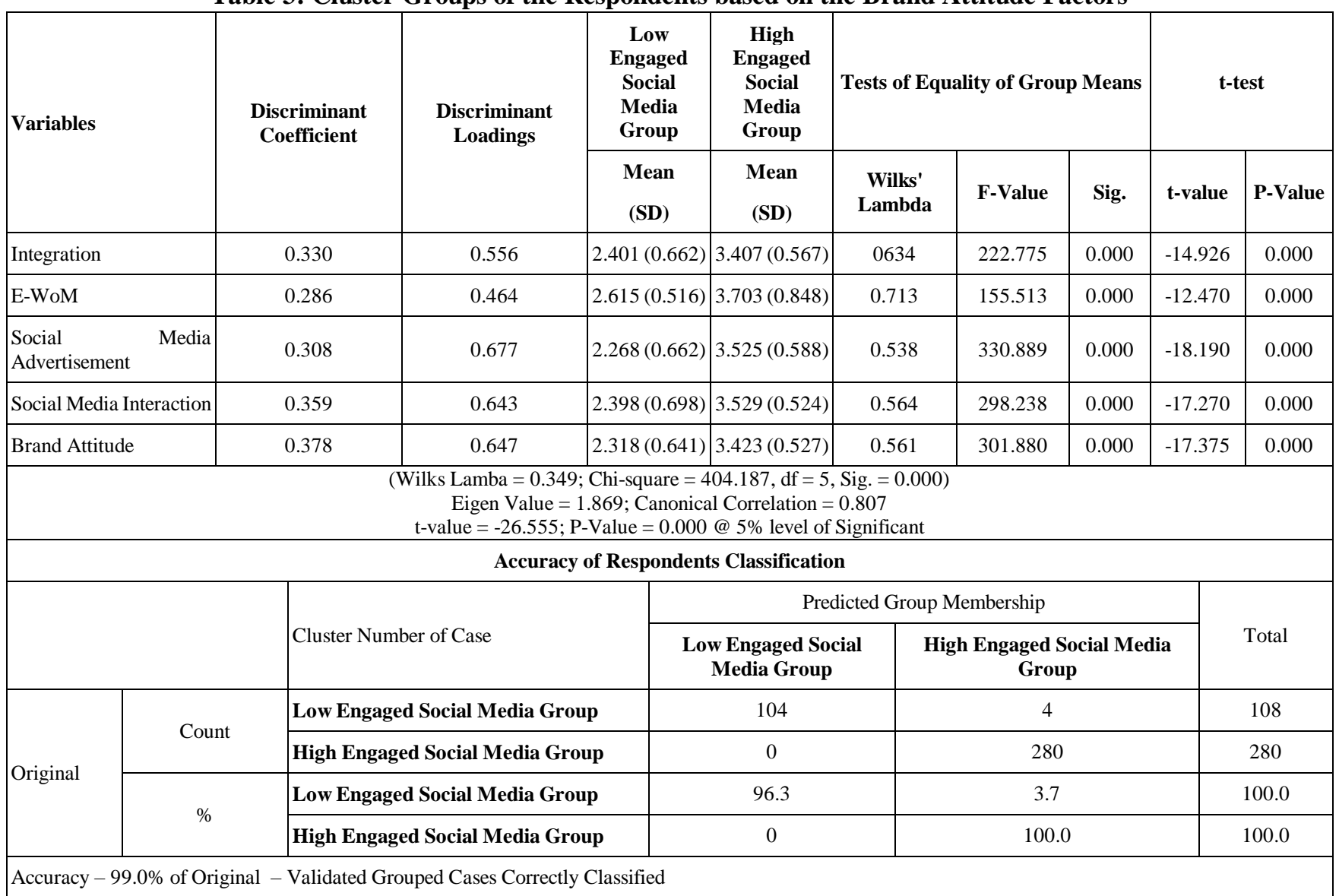

Discriminant analysis creates an equation which will minimize the possibility of misclassifying cases into their respective groups or categories. The aim of Discriminant analysis is to combine the variable score in same way so that for a single new composite variable, the Discriminant score is produced. Discriminant analysis was performed to predict a group membership between the clusters. First, the researcher examined whether there were any significant differences between groups on each factors using group means. Mean differences between two (2) cluster groups depicted in table suggest that the clusters were good discriminators as there were some deviations among the factors. The selection criteria of minimizing Wilk's Lambda and a tolerance level of 0.001 was used to generate the discriminant function to discriminate between low engaged social media group and high social media engaged group towards brand attitude. The results of the analysis are presented in table 3 . The values of Wilk's Lambda, Chi-Square value and significance are provided.

All the variables such as, integration, E-Word of Mouth, social media advertisement recommendation, social media interaction and brand attitude are found to be significant variables to discriminate of low engaged social media group and high social media engaged group towards brand attitude. The mean, SD and test of equality of group means explicit $\mathrm{F}$ statistics value are also provided for each dimensions of customer social media engagement towards brand attitude for the two cluster groups. It can be clearly seen that the differences between the two groups are significant for these all dimensions except responsiveness factor.

Another test in discriminant analysis is to examine the classificatory ability of the discriminant function, i.e., the ability to classify the cases using the discriminant function into the correct group. The classification results are provided in Table 4 . The overall classificatory ability is quite high $(99.0 \%)$, but it should be noted that the values could be slightly inflated due to classifying the same sample on which the discriminant function was developed. It is necessary to compare the classificatory ability of this model with a chance model (Hair et al, 1992). A t-test on the classification accuracy of the two models found the accuracy to be significantly different for the two models $(\mathrm{t}=-26.555 ; \mathrm{P}$ $<0.0001)$.

\section{IMPLICATION AND CONCLUSION}

The study revealed the emergence of social media in the market and the brand relationship with the customers. The technological integration saves the customer time and now it makes possible to customer to do shopping from one place via online. It is the tool generated to have communication between the consumer and retailer about the brand and product. The brand or company creates content in social media without engagement of customers towards the attraction of product and interaction with the customers to know the customizations they need and to influence the customer to make them to buy 
the products by providing attractive advertisements. It is necessary to create interaction between the customer and brand and consumer to consumer to identify the impact of communication on brand equity. E-word of mouth is to spread the word about the product via online among the customers. And it is useful to choose one product and its reviews and it helps to spread the word about the goodwill of the product or brand. Most of the famous trend in the zone of virtual marketing and branding is the growth of social networking and its admiration among people. Social media also offers new channels of communication.

\section{REFERENCES}

1. Ashley, C., \& Tuten, T. (2015). Creative strategies in social media marketing: An exploratory study of branded social content and consumer engagement. Psychology \& Marketing, 32(1), 15-27.

2. Baird, C. H., \& Parasnis, G. (2011). From social media to social customer relationship management. Strategy \& leadership.

3. Bashar, A., Ahmad, I., \& Wasiq, M. (2012). Effectiveness of social media as a marketing tool: An empirical study. International Journal of Marketing, Financial Services \& Management Research, 1(11), 88-99.

4. Brodie, R. J., Ilic, A., Juric, B., \& Hollebeek, L. (2013). Consumer engagement in a virtual brand community: An exploratory analysis. Journal of business research, 66(1), 105-114.

5. Constantinides, E., Romero, C. L., \& Boria, M. A. G. (2008). Social media: a new frontier for retailers?. In European Retail Research (pp. 1-28). Gabler Verlag, Wiesbaden.

6. Davis, R., Piven, I., \& Breazeale, M. (2014). Conceptualizing the brand in social media community: The five sources model. Journal of retailing and consumer services, 21(4), 468-481.

7. De Chernatony, L. (1999). Brand management through narrowing the gap between brand identity and brand reputation. Journal of marketing management, 15(1-3), 157-179.

8. Dehkordi, G. J., Rezvani, S., Rahman, M. S., Nahid, F. F. N., \& Jouya, S. F. (2012). A conceptual study on E-marketing and its operation on firm's promotion and understanding customer's response. International Journal of Business and Management, 7(19), 114.

9. Evans, D. (2010). Social media marketing: the next generation of business engagement. John Wiley \& Sons.

10. Falay, Z., Salimäki, M., Ainamo, A., \& Gabrielsson, M. (2007). Design-intensive born globals: a multiple case study of marketing management. Journal of Marketing Management, 23(9-10), 877-899.

11. Heinonen, K. (2011). Consumer activity in social media: Managerial approaches to consumers' social media behavior. Journal of Consumer Behaviour, 10(6), 356-364

12. Jaakkola, E., \& Alexander, M. (2014). The role of customer engagement behavior in value co-creation: a service system perspective. Journal of service research, 17(3), 247-261.

13. Kang, J., Tang, L., \& Fiore, A. M. (2014). Enhancing consumer-brand relationships on restaurant Facebook fan pages: Maximizing consumer benefits and increasing active participation. International Journal of Hospitality Management, 36, 145-155.

14. Kaplan, A. M., \& Haenlein, M. (2010). Users of the world, unite! The challenges and opportunities of Social Media. Business horizons, 53(1), 59-68.

15. Kapoor, P. S., Jayasimha, K. R., \& Sadh, A. (2013). Brand-related, consumer to consumer, communication via social media. IIM Kozhikode Society \& Management Review, 2(1), 43-59.

16. Keller, K. L., Parameswaran, M. G., \& Jacob, I. (2011). Strategic brand management: Building, measuring, and managing brand equity. Pearson Education India.

17. Kim, A. J., \& Ko, E. (2012). Do social media marketing activities enhance customer equity? An empirical study of luxury fashion brand. Journal of Business research, 65(10), 1480-1486.

18. Kotler, P., \& Zaltman, G. (1971). Social marketing: an approach to planned social change. Journal of marketing, 35(3), 3-12.

19. Lamberton, C., \& Stephen, A. T. (2016). A thematic exploration of digital, social media, and mobile marketing: Research evolution from 2000 to 2015 and an agenda for future inquiry. Journal of Marketing, 80(6), 146-172.

20. Leone, R. P., Rao, V. R., Keller, K. L., Luo, A. M., McAlister, L., \& Srivastava, R. (2006). Linking brand equity to customer equity. Journal of service research, 9(2), 125-138.
21. Lipsman, A., Mudd, G., Rich, M., \& Bruich, S. (2012). The power of "like": How brands reach (and influence) fans through social-media marketing. Journal of Advertising research, 52(1), 40-52.

22. Myers, C. A. (2003). Managing brand equity: a look at the impact of attributes. Journal of product \& brand management, 12(1), 39-51.

23. Peter, J. P., Olson, J. C., \& Grunert, K. G. (1999). Consumer behaviour and marketing strategy (pp. 329-48). London: McGraw-Hill.

24. Tolba, A. H., \& Hassan, S. S. (2009). Linking customer-based brand equity with brand market performance: a managerial approach. Journal of Product \& Brand Management, 18(5), 356-366.

25. Tuten, T. L. (2008). Advertising 2.0: social media marketing in a web 2.0 world: social media marketing in a web 2.0 world. ABC-CLIO.

26. Wang, M. C. H., \& Tang, Y. Y. (2018, July). EXPLORING THE EFFECTS OF SOCIAL MEDIA-BASED BRAND COMMUNITY ENVIRONMENT ON CONSUMER BRAND EVALUATION. In 2018 Global Marketing Conference at Tokyo (pp. 668-668).

27. Wang, X., Yu, C., \& Wei, Y. (2012). Social media peer communication and impacts on purchase intentions: A consumer socialization framework. Journal of interactive marketing, 26(4), 198-208.

28. Wolny, J., \& Mueller, C. (2013). Analysis of fashion consumers' motives to engage in electronic word-of-mouth communication through social media platforms. Journal of marketing management, 29(5-6), 562-583.

\section{AUTHORS PROFILE}

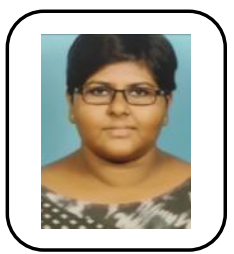

Neeraja V. R. Was full time PhD Research Scholar in Department of Commerce - Shift - II, Madaras Christian College Chennai. She awarded Swamy Vivekanandha National Fellowship for her Doctoral Research work in the field of marketing. She completed her Post Graduation from Department of Commerce, University of Madras, Chennai with specialization of International Business and Finance. She is an active researcher in participating various national and international conferences and workshops across the country.

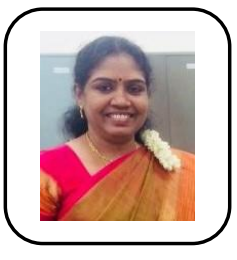

Dr. Nirmala Mohan was currently heading the Department of Commerce - Shift - II in Madras Christian College, Chennai. She is an Associate Professor having more than Two Decades of Teaching and Research Experience. She was specialized in Banking, Marketing and Financial Services. She organized various national and international conferences, colloquium and workshops for the betterment of academic fraternity. She participated and presented numerous research papers in various national and international conferences. She contributed many academic writings and contribution in the leading journals in the field of commerce and management. She is panel member and subject expert for the various city colleges in Chennai. She is currently guiding Research Scholars leading to Pre-Doctoral and Doctoral Degrees from University of Madras. 